Original Research Article

\title{
Antiproliferative effects of Vanilla planifolia leaf extract against breast cancer MCF-7 cells
}

\author{
Vijaybabu Kaliappan ${ }^{1}$, Punnagai Kumaravelu ${ }^{2 *}$
}

\begin{abstract}
${ }^{1}$ Department of Pharmacology, Annapoorna Medical College, Salem, Tamil Nadu, India ${ }^{2}$ Department of Pharmacology, Sri Ramachandra Medical College \& Research Institute SRIHER, Chennai, Tamil Nadu, India
\end{abstract}

Received: 28 November 2018 Accepted: 06 December 2018

*Correspondence to: Dr. Punnagai Kumaravelu, Email:punnagaiguna@ hotmail.com

Copyright: (C) the author(s), publisher and licensee Medip Academy. This is an openaccess article distributed under the terms of the Creative Commons Attribution NonCommercial License, which permits unrestricted noncommercial use, distribution, and reproduction in any medium, provided the original work is properly cited.

\begin{abstract}
Background: Breast cancer is the most common cancer disease among females in India and worldwide. This needs a critical research for finding the drugs to treat breast cancer with less side effects. The aim of the present study is to reveal the anti-proliferative effects of vanilla extract against MCF-7 cells.

Methods: To reveal anti proliferative effects of vanilla leaf extract, MTT assay, cell cycle analysis and DNA fragmentation assay was performed as per standard protocols.

Results: MTT assay showed decrease in cell viability with increase of dose of extract and revealed IC50 value at $31.2 \mu \mathrm{g} / \mathrm{ml}$. DNA fragmentation was seen in extract treated cells.

Conclusions: The results of the present study confirm the antiproliferative property of vanilla leaf extract in MCF-7 cells. This study results conclude vanilla leaf extract as an effective plant source medicament for treating breast cancer.
\end{abstract}

Keywords: Breast cancer, DNA fragmentation, IC50, MTT, Phytochemicals

\section{INTRODUCTION}

Breast cancer is the most commonly diagnosed disease in females and also a major public health problem which needs research to provide a specific treatment. ${ }^{1}$ Epidemiological studies revealed that breast cancer had a mortality incidence of rural to urban is $66 / 8$ in India. $^{2}$ Taking adverse events of chemotherapy in to consideration, natural products are being explored for anti cancerous effects in the recent researches. MCF-7 cells were widely used for screening anti cancer drugs against breast cancer. ${ }^{3}$ Vanilla planifolia (vanilla)is a well-known plant which is extensively used as flavouring agent in various food and medicinal products. Because of growing interest for natural products or phytochemicals and their medicinal values, recent studies had shown many medicinal properties of $V$. planifolia. The flavouring agent was obtained majorly from beans of vanilla. This included vanillin, vanillic acid which comprised 250 compounds altogether., ${ }^{4,5}$

Another study revealed that out of 200 compounds, 26 compounds were at a concentration of $1 \mathrm{mg} .{ }^{6-8}$ Vanilla was first discovered by Aztecs who were Mexicans during 1300's. Aztecs were the first to use it as flavouring agent in drinks. This crop was native to Mexico, due to absence of natural pollinator outside Mexico as stated by the 
botanist Charles Morren and this led to the discovery of vanilla's artificial pollination. ${ }^{9}$ With this it has explored to other parts of world. Use of vanilla plant as health food agent had ethnical variation. Aztecs used for its stimulant, carminative and aphrodisiac properties. In Venezuela it is used for treating fever and spasm. Argentinian used it for spasms and sexual dysfunctions. Palauans used this plant for treating dysmenorrhoea, fever and hysteria. ${ }^{10}$ Recently Sophie et al, has revealed its protective properties against free radicals in skin. ${ }^{11}$ The leaf extracts of vanilla species were revealed to possess compounds that have mosquito larvicidal properties at a dose of $0.1-0.2 \mathrm{mg} / \mathrm{ml} .{ }^{12} \mathrm{In}$ this study we used extracts of leaves of vanilla for screening its anti-cancerous property against breast cancer cells, MCF7 cells. With this back ground, we aimed to hypothesise that vanilla leaf extract can be beneficial in treatment of breast cancer.

\section{METHODS}

MCF-7 cells were bought from National Centre for Cell Sciences, Pune. Vanilla leaves were purchased and authenticated. The leaves were shade dried and powdered. The powdered was further treated with ethanol to obtain ethanolic extract. The procedure followed Sun et al, with slight modifications. ${ }^{12}$ Two hundred grams of powdered extract was treated with $500 \mathrm{ml}$ of ethyl alcohol (98\%) and allowed to stand for 2 days. Then the procedure was repeated twice with the precipitate. The obtained alcohol was freezed and filtered. The obtained solution was lyophilized to produce powdered extract of vanilla leaves.

\section{Cytotoxicity assay}

The cytotoxicity assay included 3-(4,5-dimethyl-2thiazolyl)-2,5-diphenyl-tetrazolium bromide (MTT) assay. Culture media specific to this assay was prepared as suggested by previous literature. ${ }^{13,14}$ MCF-7 cells were treated with MTT and sample with a dose concentration of $1000 \mu \mathrm{g} / \mathrm{ml}$ to $7.8 \mu \mathrm{g} / \mathrm{ml}$ dilution. This was compared with control cells. The reaction absorbance was observed by spectrophotometer at 570nm. The cell viability was calculated as per standard formula. ${ }^{14}$

\section{DNA fragmentation assay}

The assay method was performed as described by Wyllie et al. ${ }^{15}$ The procedure of the assay was depicted in Figure 1. UV transilluminator (Uvitec, England) was used for analysing the DNA fragmentation.

\section{Flowcytometry analysis}

MCF-7 cells taken in a Petri dish of $6 \mathrm{~cm}$ (105 cells) and incubated overnight. Later the medium was changed and DMSO was added to the cells, then incubated for 24 hours. The cells and media were centrifuged at $200 \mathrm{~g}$ for $7 \mathrm{~min}$ and $4^{\circ} \mathrm{C}$. Ice cold phosphate buffered saline containing $\operatorname{EDTA}(5 \mathrm{mM})$ was used to wash the cells twice. Then the cells were re-suspended in PBS/EDTA $(100 \mathrm{ml})$ and fixed with $70 \% 1 \mathrm{ml}$ ethanol. $50 \mathrm{ml}$ PI was added after incubating the cells with $50 \mathrm{ml}$ RN'ase. The cells were analysed with flow cytometer as per manufacturer's protocol.

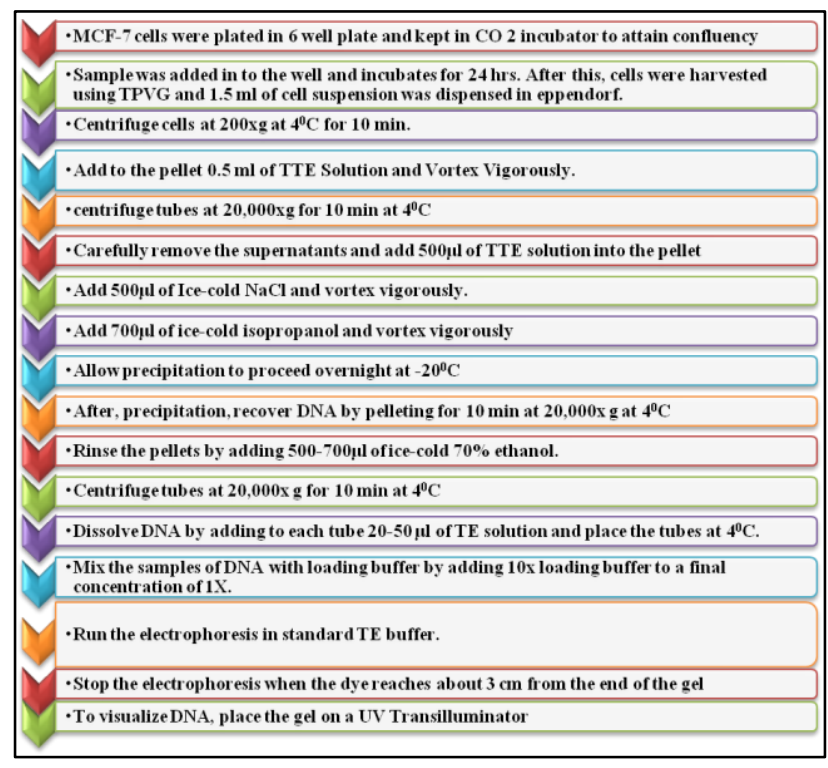

Figure 1: DNA analysis by gel electrophoresis method.

\section{RESULTS}

\section{MTT assay}

The leaf extract showed a decrease in cell viability with increase in concentration of the extract in a dose dependent manner (Figure 2).

The half maximal inhibitory concentration (IC50) revealed by MTT assay was $31.2 \mu \mathrm{g} / \mathrm{ml}$ at a dilution of $1: 16$. The MCF-7 cell viabilty with various concentrations of vanilla leaf extract was shown the Table 1 below.

It cell viability ranged between $13.32 \%$ and $62.42 \%$ at an extract concentrations ranging between $1000 \mu \mathrm{g} / \mathrm{ml}$ and 7.8 $\mu \mathrm{g} / \mathrm{ml}$.

Table 1: Anticancer effect of Vanilla leaf on MCF 7 cells.

\begin{tabular}{|lll|l|}
\hline $\begin{array}{l}\text { Concentration } \\
(\boldsymbol{\mu g} / \mathrm{ml})\end{array}$ & Dilutions & $\begin{array}{l}\text { Absorbance } \\
(\mathbf{O . D})\end{array}$ & $\begin{array}{l}\text { Cell- } \\
\text { viability } \\
(\%)\end{array}$ \\
\hline 1000 & Neat & 0.201 & 13.32 \\
\hline 500 & $1: 1$ & 0.308 & 20.41 \\
\hline 250 & $1: 2$ & 0.415 & 27.50 \\
\hline 125 & $1: 4$ & 0.523 & 34.65 \\
\hline 62.5 & $1: 8$ & 0.631 & 41.81 \\
\hline 31.2 & $1: 16$ & 0.729 & 48.31 \\
\hline 15.6 & $1: 32$ & 0.833 & 55.20 \\
\hline 7.8 & $1: 64$ & 0.942 & 62.42 \\
\hline Cellcontrol & - & 1.509 & 100 \\
\hline
\end{tabular}




\section{Apoptosis induction by vanilla leaf extract}

The DNA fragmentation was revealed in this assay. The vanilla leaf extract treated MCF-7 cells showed fragmented DNA in comparison to control, depicted in Figure 3. This confirms the antiproliferative effects of the vanilla leaf extract.

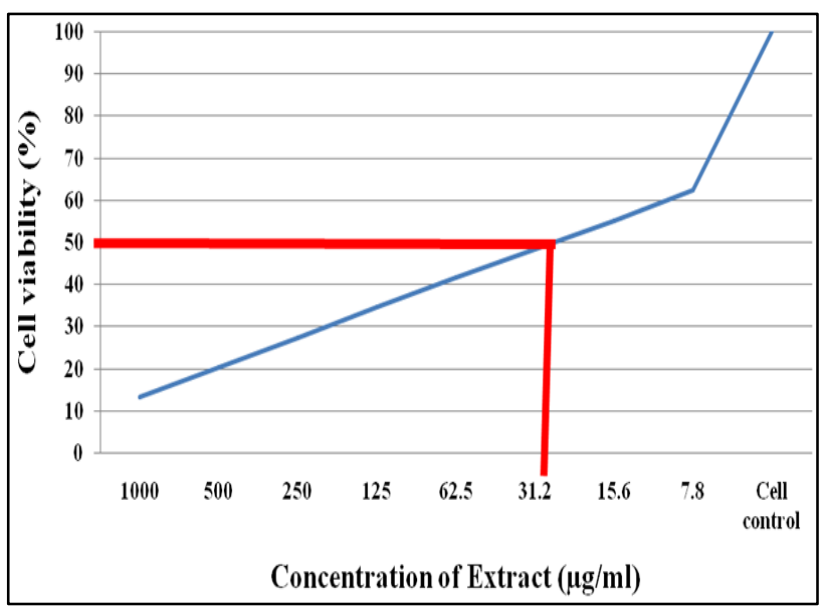

Figure 2: Cell viability assay of MCF-7 cells.

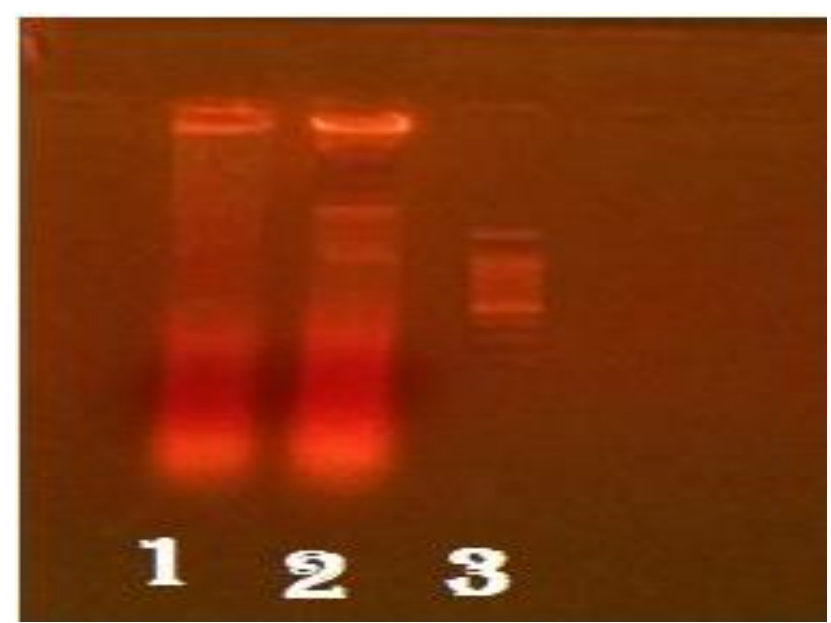

Gel electrophoresis of extracted DNA. 1-indicates the control lane, 2-indicates the vanilla leaf extract treated lane, 3 -indicates the marker.

\section{Figure 3: Gel electrophoresis method for DNA analysis.}

\section{Effects of Vanilla leaf extract on MCF-7 cell cycle}

Control MCF-7 cells showed $97.6 \%$ gated cells. Dead cells were found to be $10 \%$. Majority (64\%) of the cells were found to be in G0/G1 stage. 13\% of the cells were in S phase and $11 \%$ were in $\mathrm{G} 2 / \mathrm{M}$ phase. In vanilla leaf extract treated MCF-7 cells, $16 \%$ cells showed apoptosis. It was higher than the control. G0/G1 stage showed $59.72 \% .14 \%$ of the cells were in S phase and G2/M phase (Figure 4). Sub G1 population of cells is considered more for the analysis of viable cells and apoptosis.

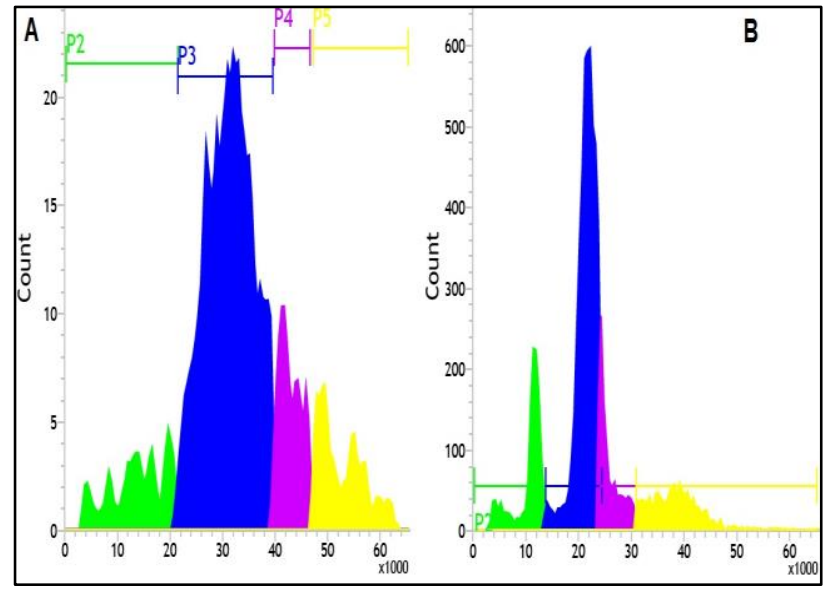

A- control MCF-7 cells, B- extract treated MCF-7 cells, P2-, P3, P4-, P5-.

Figure 4: Cell cycle analysis of control and extract treated MCF-7 cells.

\section{DISCUSSION}

MCF-7 is a widely used cell line in breast cancer research since years and proved to be a perfect in-vitro model for screening drugs for treating breast cancer or investigating the breast cancer pathology. ${ }^{16,17}$ This cell line has provided vast data compared to other breast cancer cell lines. ${ }^{18}$ These cells are non-invasive, poorly aggressive and have low metastatic potential. ${ }^{19,20}$ Vanilla plant was known for many medicinal properties but its anti-cancerous properties were little known till date. Many phytochemicals were identified in this plant that possess various biological activities. These phytochemicals were used for treating many ailments since decades. It was shown to possess DNAdependent protein kinase (DNA-PK) inhibitory action which may be responsible for anticancerous effects. ${ }^{21} \mathrm{~A}$ study by $\mathrm{Ho} \mathrm{K}$ et al, has revealed the anticancerous property of vanilla extract which attained $\mathrm{G} 0 / \mathrm{G} 1$ arrest at a dose of $200 \mathrm{microg} / \mathrm{ml}$ and G2/M arrest at a dose of 1000 microg/ml. This study concluded that vanilla extract induced apoptosis. ${ }^{22}$ In a study, the effect of vanilla extract was observed on growth and metastasis of BALB/c mice 4T1 mammary adenocarcinoma. Orally administered vanilla extract significantly reduced lung metastasized colonies. Vanilla extract inhibited matrix metallopeptidase 9 (MMP-9) secreted by cancer cells which decreased invasion and migration of cancer cells in an in-vitro study. This study concluded vanilla extract to have anti-metastatic activity. ${ }^{23}$ Anti-mutagenic property of vanilla extract was revealed for first time by King et al. It induced DNA damage which elicits recombinational DNA repair and further reduced spontaneous mutation. ${ }^{24}$ Keshava et al, showed the protective effects of vanilla extract on radiation induced chromosomal damage in V79 cells and indicated anticlastogenic property of vanilla extract. ${ }^{25}$ Ohta et al, study investigated vanilla extract on recombination frequency with two plasmid DNA suggested the antimutagenic property of vanilla extract. The frequency of plasmid recombination was significantly higher in presence of vanilla extract. They found that this effect was 
due to enhancement of rec A-dependent, error free, pathway of post replication. ${ }^{26}$ The anti-proliferative properties of the vanilla leaf extract was shown in this study using cytotoxicity assay and gel electrophoresis DNA extraction. MTT assay showed effective anticancerous activity of extract against MCF-7 cells. The assay detects the reduction of MTT salt to blue formazan product by mitochondrial dehydrogenase, which indicates the cell viability. ${ }^{27}$ The cell viability of MCF-7 cells decreased with increase of extract dose confirming the anticancerous property of the extract with IC50 value at $31.2 \mu \mathrm{g} / \mathrm{ml}$. Several naturally derived alkaloids with prospective anticancer properties against MCF-7 cells, such as berberine, evodiamine, and piperine, have already been reported by other authors. ${ }^{28}$ And the reported IC50 values of above mentioned alkaloid compounds suggest that vanilla extract exhibits considerable inhibition than above mentioned alkaloids in MCF-7 cells. ${ }^{29-31}$ Graidist et al, revealed IC50 of an extract against MCF-7 cells to be $22.31 \pm 0.83 \mu \mathrm{g} / \mathrm{mL}^{32}$ E.guineensis extract IC50 value determined by MTT assay was $15.00 \mu \mathrm{g} / \mathrm{mL}$ against MCF7 breast cancer cells. ${ }^{33}$ Presence of DNA fragmentation showed by gel electrophoresis method confirms the antiproliferative effects and apoptosis induction of vanilla leaf extract. DNA fragmentation is an important sign of apoptosis revealing the inhibition of DNA replication and internucleosomal cleavage. ${ }^{34,35}$ Anticancer drugs that cause apoptosis selectively to cancer cells, with less side effects to normal cells, are considered important for therapeutic purposes. ${ }^{36,37}$ In summary, we suggest that vanilla leaf extract demonstrates selective inhibition of MCF-7 breast cancer cells through inhibition of apoptosis. Furthermore, vanilla leaf extract caused up-regulation DNA fragmentation in MCF-7, which suggests activation of apoptosis. These findings will help to give a basic understanding on the antiproliferative action of vanilla leaf extract in future studies.

\section{CONCLUSION}

The results of the present study conclude that vanilla leaf extract induces cytotoxicity and apoptosis induced cell death in MCF-7 breast cancer cells. Vanilla leaf extract might contain the leading molecule which may be developed as chemotherapeutic agent for treating breast cancer of estrogen receptor positive type. Further research is required to characterize and understand the molecular aspects of the anticancerous effects of the extract.

Funding: No funding sources Conflict of interest: None declared

Ethical approval: The study was approved by the Institutional Ethics Committee

\section{REFERENCES}

1. Gunduz M, Gunduz E. Breast Cancer-Carcinogenesis, Cell Growth and Signalling Pathways. 2011 Nov 30.
2. Anonymous. Three Year Report of Population Based Cancer Registries 2012-2014. Indian Council of Medical Research (ICMR), Bangalore, India; 2016.

3. Baguley BC and Leung E: Heterogeneity of Phenotype in Breast Cancer Cell Lines. In: Breast Cancer Carcinogenesis, Cell Growth and Signalling Pathways (Gunduz M, Gunduz E, eds. Rijeka, InTech; 2011:245-256.

4. Guarino PA, Brown SM. Liquid chromatographic determination of vanillin and related flavor compounds in vanilla extract: cooperative study. J Association Official Analytical Chemists (USA). 1985;68:1198-201.

5. Dignum MJ, Kerler J, Verpoorte R. Vanilla production: technological, chemical, and biosynthetic aspects. Food Rev Int. 2001 Feb 4;17(2):119-20.

6. Westcott RJ, Cheetham PS, Barraclough AJ. Use of organized viable vanilla plant aerial roots for the production of natural vanillin. Phytochemistry. 1993 Dec 22;35(1):135-8.

7. Bettazzi F, Palchetti I, Sisalli S, Mascini M. A disposable electrochemical sensor for vanillin detection. Analytica Chimica Acta. 2006 Jan 5;555(1):134-8.

8. Sharma A, Verma SC, Saxena N, Chadda N, Singh NP, Sinha AK. Microwave-and ultrasound-assisted extraction of vanillin and its quantification by highperformance liquid chromatography in Vanilla planifolia. J Separation Sci. 2006 Mar;29(5):613-9.

9. Reineccius G. Source book of flavours. New Delhi: CBS Publishers and Distributors. $2^{\text {nd }}$ Ed. New York: Chapman \& Hall, Inc;1997:351-360.

10. Duke JA, Bogenschutz-Godwin MJ, duCellier J, Duke PK. CRC handbook of medicinal spice. Boca Raton, FL: CRC Press;2003;303-308.

11. Sophie L, Francois MJ. Use of a composition containing a vanilla extract to protect the skin against superoxide radicals or to limit the appearance of sunburn cells. French Patent. FR 2003;2837384.

12. Sun R, Sacalis JN, Chin CK, Still CC. Bioactive aromatic compounds from leaves and stems of Vanilla fragrans. J Agricultural Food Chem. 2001 Nov 19;49(11):5161-4.

13. Mosmann T. Rapid colorimetric assay for cellular growth and survival: application to proliferation and cytotoxicity assays. J Immunol Methods. 1983;65:5563.

14. Vijayarathna S, Sasidharan S. Cytotoxicity of methanol extracts of Elaeis guineensis on MCF-7 and Vero cell lines. Asian Pacific J Trop Biomed. 2012 Oct $1 ; 2(10): 826-9$.

15. Wyllie AH. Cell death. In:Cytology and Cell Physiology. Fourth Edition. Academic Reas, Inc;1987:755-785.

16. Leung EY, Kim JE, Askarian-Amiri M, Joseph WR, McKeage MJ, Baguley BC. Hormone resistance in two MCF-7 breast cancer cell lines is associated with reduced mTOR signaling, decreased glycolysis, and increased sensitivity to cytotoxic drugs. Frontiers in oncology. 2014 Sep 3;4:221. 
17. Shirazi FH: Remarks in Successful Cellular Investigations for Fighting Breast Cancer Using Novel Synthetic Compounds. In: Breast Cancer - Focusing Tumor Microenvironment, Stem Cells and Metastasis (Gunduz M, Gunduz E, eds. Rijeka, In:Tech; 2011:85102.

18. Sweeney EE, Mcdaniel RE, Maximov PY, Fan P, Craig V. Models and Mechanisms of Acquired Antihormone Resistance in Breast Cancer: Significant Clinical Progress Despite Limitations. Horm Mol Biol Clin Investig 2013;9:143-163.

19. Gest C, Joimel U, Huang L, Pritchard LL, Petit A, Dulong $\mathrm{C}$, et al. Rac3 induces a molecular pathway triggering breast cancer cell aggressiveness: differences in MDA-MB-231 and MCF-7 breast cancer cell lines. BMC cancer. 2013 Dec;13(1):63.

20. Adami ER, Corso CR, Turin-Oliveira NM, Galindo CM, Milani L, Stipp MC, et al. Antineoplastic effect of pectic polysaccharides from green sweet pepper (Capsicum annuum) on mammary tumor cells in vivo and in vitro. Carbohydrate polymers. 2018 Dec 1;201:280-92.

21. Durant S, Karran P. Vanillins-a novel family of DNAPK inhibitors. Nucleic Acids Res. 2003 Oct 1;31(19):5501-12.

22. Ho K, Yazan LS, Ismail N, Ismail M. Apoptosis and cell cycle arrest of human colorectal cancer cell line HT-29 induced by vanillin. Cancer Epidemiol. 2009 Aug 1;33(2):155-60.

23. Lirdprapamongkol K, Sakurai H, Kawasaki N, Choo MK, Saitoh Y, Aozuka Y, Singhirunnusorn P, Ruchirawat S, Svasti J, Saiki I. Vanillin suppresses in vitro invasion and in vivo metastasis of mouse breast cancer cells. Eur J Pharmaceuti Sci. 2005 May 1;25(1):57-65.

24. King AA, Shaughnessy DT, Mure K, Leszczynska J, Ward WO, Umbach DM, et al. Antimutagenicity of cinnamaldehyde and vanillin in human cells: Global gene expression and possible role of DNA damage and repair. Mutation Research. 2007 Mar 1;616(1):60-9.

25. Keshava C, Keshava N, Ong TM, Nath J. Protective effect of vanillin on radiation-induced micronuclei and chromosomal aberrations in V79 cells. Mutation Research/Fundamental and Molecular Mechanisms of Mutagenesis. 1998 Feb 2;397(2):149-59.

26. Ohta T, Watanabe M, Shirasu Y, Inoue T. Postreplication repair and recombination in uvrA umuC strains of Escherichia coli are enhanced by vanillin, an antimutagenic compound. Mutation
Research/Fundamental and Molecular Mechanisms of Mutagenesis 1988;201(1):107-12.

27. Momtazi-borojeni A, Behbahani M, Sadeghi-aliabadi H. Antiproliferative activity and apoptosis induction of crude extract and fractions of avicennia marina. Iranian J Basic Med Sci. 2013 Nov;16(11):1203.

28. Shrestha RL, Jha RN. An isoquinoline alkaloid, Protopine from Corydalis govaniana growing in Himalayan region of Nepal. J Nepal Chem Soc. 2011;28:106-9.

29. Mehra K, Garg HS, Bhakuni DS, Khanna NM. Alkaloids of Corydalis govaniana Wall: Isolation and structures of three new tetrahydroprotoberberine alkaloids, Corygovanine, govadine and govanine and of a new phthalideisoquinoline base biscuculline. Indian Journal of Chemistry 1976;14(8):844-8.

30. Buolamwini JK. Novel anticancer drug discovery. Curr Opin Chem Biol. 1999 Aug 1;3(4):500-9.

31. Gu J, Liu Y, Xie B, Ye P, Huang J, Lu Z. Roles of tolllike receptors: From inflammation to lung cancer progression. Biomed Reports. 2018 Feb 1;8(2):12632.

32. Graidist P, Martla M, Sukpondma Y. Cytotoxic activity of Piper cubeba extract in breast cancer cell lines. Nutrients. 2015 Apr 10;7(4):2707-18.

33. Vijayarathna S, Sasidharan S. Cytotoxicity of methanol extracts of Elaeis guineensis on MCF-7 and Vero cell lines. Asian Pacific J Trop Biomed. 2012 Oct $1 ; 2(10): 826-9$.

34. Wyllie AH. Glucocorticoid-induced thymocyte apoptosis is associated with endogenous endonuclease activation. Nature. 1980;284:555-6.

35. Sivakumaran N, Samarakoon SR, Adhikari A, Ediriweera MK, Tennekoon KH, Malavige N, et al. Cytotoxic and Apoptotic Effects of Govaniadine Isolated from Corydalis govaniana Wall. Roots on Human Breast Cancer (MCF-7) Cells. BioMed Res Int. 2018;2018.

36. Buolamwini JK. Novel anticancer drug discovery. Curr Opin Chem Biol. 1999 Aug 1;3(4):500-9.

37. Cotter TG. Apoptosis and cancer: the genesis of a research field. Nature Rev Cancer. 2009 Jul;9(7):5017.

Cite this article as: Kaliappan V, Kumaravelu P. Antiproliferative effects of Vanilla planifolia leaf extract against breast cancer MCF-7 cells. Int J Basic Clin Pharmacol 2019;8:51-5. 